\title{
Co-resident Parents and Young People Aged 15-34: Who Does What Housework?
}

\author{
Lyn Craig, Abigail Powell \& Judith E. Brown
}

\begin{abstract}
Young adults are now more likely to co-reside with their parents than previous generations, but domestic work patterns among this family type are largely unexplored. This study addresses this issue using Australian Bureau of Statistics Time Use Surveys (1992, 1997, 2006) and Poisson-Gamma regression analyses. It examines patterns in and correlates of domestic labor in two-generation households in which young people aged 15-34 co-reside with their parents $(n=1,946$ households comprised of 2,806 young people and 5,129 parents). It differentiates between routine indoor tasks (cooking, cleaning, laundry), non-routine tasks (outdoor work, household management and maintenance, car care) and grocery shopping. Predictors of more time in some domestic activities by young people include being in neither employment nor education/training (NEET), being older, having a single parent and being in a non-English speaking household (young women). Young people being NEET, or female, are associated with less cooking time for mothers, but in the main when young people do perform domestic activities, they do not relieve their parents of those same activities, suggesting more time is spent by the household in total.
\end{abstract}

\section{Introduction}

This paper investigates predictors of domestic labor in two-generation households in which young people aged 15-34 are co-resident with their parents. We know much about the gender division of housework among adult couples (see Bianchi and Milkie 2010, for an overview), and the literature on the domestic work of children and teenagers is growing (Salman Rizavi and Sofer 2010;

Evertsson 2006; Miller 2012). However, the domestic work of co-resident young adults and their parents is largely unexplored (Mitchell 2004). This is a significant knowledge gap given that young people more commonly co-reside with their parents beyond the teenage years now than in times past (e.g. Mitchell 2004; ABS 2013; U.S. Census Bureau 2011 2001), and divisions of domestic labor are a marker of workload and gender equity (Craig and Bittman 2008). Using nationally representative time use data from the Australian Bureau of Statistics (ABS) we address this gap by examining the domestic contribution of young adults, together with their parents' domestic labor time.

The transition to adulthood is a life stage in which young people are establishing their identity and learning to take control of their life (Erikson 1959). In western societies the transition is a loosely defined process, consisting of a number of milestones that reflect aspects of independence and together indicate adult autonomy (Furlong 2009). Over the last century, the markers of the transition to adulthood in the US and similar countries were generally thought to include completing education, securing stable employment, leaving the family home, marrying or cohabiting, and having children (Furstenberg et al. 2004; Mahaffy 2004). In recent decades achieving these milestones has become less predictable and the pace at which they are reached slower (Tanner and Arnett 2009; Furstenberg et al. 2004; Bell et al. 2007; Cobb-Clark 2008; Mandic 2008; Raley et al. 2007), such that the period during which young people transition to adulthood has lengthened (Swartz et al. 2011; Hendry and Kloep 2012). Whereas during the mid-twentieth century most people transitioned to adulthood by their early to mid-20s, the contemporary transition is considered by many scholars to encompass the age range 18-34 (Mahaffy 2004; Furstenberg et al. 2004; Furlong 2009), and to be an extended period in which individuals may be independent in some contexts but not fully autonomous in others (Tanner and Arnett 2009). 
One manifestation of the extended transition has been a rise in the number of households in which young people co-reside with their parents beyond the teenage years. In $200141 \%$ of young Canadians aged 20-29 lived with their parents, compared with $27 \%$ in 1981 (Mitchell 2004). In Australia the trend has been less marked, but still apparent. In $197621 \%$ of young people aged 18-34 lived at home, compared to $29 \%$ in 2011 (ABS 2013). In the US, the proportion of young people coresident with parents increased from $22 \%$ in 2001 to $31 \%$ in 2011 (US Census Bureau 2001, 2011). Leaving the parental home is also less likely to be a one-way, one-time event. Recent Canadian data showed that of young adults aged $20-29,28 \%$ of young women and $33 \%$ of young men returned home at least once after they first left (Mitchell 2004). Australian patterns are similar, with, more than $40 \%$ of young Australians who leave home returning at least once for either financial, emotional or practical reasons (de Vaus 2004).

Lives of family members are intricately linked, and an obvious corollary of young people taking longer to reach full autonomy is their parents continuing to support them beyond their teenage years (Greenfield and Marks 2006; Swartz et al. 2011; Fingerman et al. 2009). Recent US research estimated that nearly a quarter of the financial cost of raising children is incurred when they are aged between 18 and 34, during which time the outlay averages \$US38,000 (Schoeni and Ross 2004). While co-residence is a form of financial subsidy, in that it may save young people living expenses, it is a particular form of subsidy, because it does not necessarily involve direct money transfers, and may also bring in-kind support in the form of domestic services.

Patterns of domestic labor across co-resident young adult-parent households are largely unknown, however, (Mitchell 2004). They likely vary according to the particular circumstances, characteristics and resources of both parents and young people. They also likely vary across different types of domestic labor. Domestic labor is highly diverse, encompassing activities that need to be done daily, and/or at regular times, and activities that can be done to a more flexible timetable as and when the need arises (Sullivan 1997). Indoor activities including cooking, cleaning and laundry are generally regarded as routine and stereotypically female. Non-routine tasks such as outdoor work, household management and maintenance are more stereotypically male, and grocery shopping, traditionally a female activity, may now be more gender neutral (Baxter 2002; Bianchi and Milkie 2010).

We expect young people and their parents to participate differently in these forms of domestic labor. A qualitative US study found parents regularly prepared meals and did grocery shopping for adult children living at home, but doing their laundry was less frequent (Veevers and Mitchell 1998). This suggests that parents may do more of the regular activities that are essential to the smooth running of the household, and/or which can be done for all household members at once, while young people do domestic activities for their own self-maintenance. Young people may also do more infrequent tasks such as putting out the garbage, sweeping the path, or car maintenance, than routine daily activities. Moreover, they may participate in routine activities, but only irregularly, for example cooking or cleaning sometimes but not often. To explore this it is necessary to examine not only the amount of time spent in various domestic activities, but the frequency with which they are done and in a new contribution to knowledge we do so in this paper.

To date almost all quantitative research into young peoples' housework has looked at the time use of children and teenagers (Romich 2007; Larson and Verma 1999; Bonke 2010; Wight et al. 2009; Miller 2012; Evertsson 2006). An exception is Gauthier and Furstenberg (2002), who used time diaries to describe the time allocation of young people aged 18-34. However, they amalgamated housework and childcare together, and did not break down the sample further by age, or by the young people's living arrangements, including whether or not they shared a dwelling with their parents (Gauthier and Furstenberg 2002). To our knowledge no studies have yet investigated specific household tasks performed by each generation when young adults live at home, or identified the personal, family and household characteristics associated with both parents' and young peoples' 
housework in co-resident households. To begin to fill this gap in knowledge we explore what predicts domestic work among young people and co-resident parents. We are particularly interested in whether and what young people contribute in terms of domestic work and how this may be associated with mothers' and fathers' amount and composition of domestic work. For example, do the same characteristics that predict young people contribute more to domestic work also predict that mothers and/or fathers do less? In other words, do mothers' and fathers' contributions to domestic labor decrease if young people contribute? There are a number of characteristics known to be associated with domestic labor, and we outline below how they might be relevant to co-resident households.

\section{Gender}

A large body of research documents gender divisions in domestic work among adults. Women do more domestic labor overall, and also more of the routine and indoor tasks; men's domestic labor is lower, and includes proportionally more non-routine tasks such as outdoor work and car maintenance (see Bianchi and Milkie 2010 for an overview). Research also finds that girls do more housework than boys, and that there are gender differences in the type of housework performed by children and teenagers (Coltrane 2007; Dodson and Dickert 2004; Salman Rizavi and Sofer 2010; Gager et al. 1999; Evertsson 2006). Teenage daughters face greater expectations than teenage sons to contribute to domestic chores (Manke et al. 1994; Evertsson 2006), and co-resident adult sons are more likely to report receiving domestic services than daughters (Mitchell 2004). This seems particularly so in families with more traditional attitudes, including those from cultural backgrounds with more tightly defined gender roles (Mitchell 2004; Mahaffy 2004). We expect the influence of gender to be pervasive, with differences in associations between gender, domestic labor and factors including young people's age, time availability, household demand and resources, described below. For this reason, we stratify our multivariate analyses by gender.

\section{Young Peoples' Age}

There are strong age norms influencing parental support to young people (Mahaffy 2004; Settersten et al. 2005). To some extent this is related to need; children require more support the younger they are (Fingerman et al. 2009), but direct age effects are generally found, independent of individual circumstances (Hartnett et al. 2012). Moving back into the parental home seems to be an exception to this general rule, with no upper age limit that makes it unacceptable (Settersten and Hagestad 1996). Nonetheless, those that do co-reside at older ages may be expected to contribute more to the running of the household. Teenagers are most likely to be recipients of parental domestic services, since coresidence in the teenage years is most usual (Settersten et al. 2005). Associations between age and domestic work may not be straightforward, however. Older young adults may be more capable of performing domestic work in terms of both skills and maturity (Gager et al. 1999) but younger children may have more time to contribute (Brannen 1995). Moreover, many parents seek to develop domestic competence in their children (Evertsson 2006), and teaching domestic skills through requiring them to do chores may be more appropriate in the teenage years than when children are older. Also, it may be more possible for parents to press younger children to perform particular tasks.

For parents, we expect having older young people at home to be associated with less domestic work and less time in routine tasks, than having teenagers. Again, however, associations may not be straightforward, as it may be difficult for some parents to desist from providing domestic services to children. Kloep and Hendry (2010) find, for example, that some mothers, particularly, are reluctant to 'let go' of their children and adopt various strategies to 'hold on' to them, including performing domestic services. 


\section{Time Availability}

The amount of time spent in domestic labour is, in part, dependent on how much time people have available and what other demands they have on their time (Gager et al. 1999). We therefore expect young people's domestic labor to vary according to their economic status, specifically whether they are studying, employed or not in employment or education/training (NEET). Parents' time in domestic labor may also vary according to their child's economic status. Parents' support to children has been found to be higher if they are seen as needing it more (for example having emotional problems, being of younger age) or, at the other end of the spectrum, if they are doing well in other areas of their lives (Fingerman et al. 2009). Accordingly parents may be more prepared to support employed children, or those studying, with domestic services, while expecting NEET children to contribute through unpaid work. It could also be that some young people are NEET in order to perform domestic services for parents who require more domestic support.

Mothers' time availability, reflected in their employment status, is known to be associated with their own domestic labor time (Craig and Mullan 2009) but it is unclear whether mothers' employment would be associated with variation in young peoples' domestic labor. Some studies suggest that children and teenagers do more domestic work with stay-at-home, rather than employed, mothers (Salman Rizavi and Sofer 2010), but others have found no such link (Wight et al. 2009; Gager et al. 1999). Fathers' employment status varies less than mothers'; most are employed full-time (Craig and Mullan 2009). Men working part-time or not employed may allocate more of their own time to domestic labor, but it is not known whether fathers' employment status is likely to be related to differences in co-resident young adults' domestic labor.

\section{Family Structure}

Family structure has also been shown to be associated with domestic time allocation, for reasons including parental time availability. Having a single parent has been found to predict children and teenagers will do more housework (Bonke 2010; Miller and Bowd 2010; Gager et al. 1999) although not in all studies (Wight et al. 2009). We expect that because they have no partner to share chores with, sole parents would require more domestic contribution from co-resident young adults, of both genders, but that associations would be strongest for females, as has been found for younger children (Gager et al. 1999). Research has found family structure affects the domestic time allocation of parents, with sole mothers doing less, and sole fathers doing more, than their partnered counterparts (Craig 2006; Craig and Mullan 2011).

\section{Household Resources}

Parents with more education and higher income provide more material assistance to grown children than do parents with fewer resources (Schoeni and Ross 2004), but may expect more egalitarian contribution to domestic labor from co-resident young adult offspring. Gender attitudes are generally more liberal amongst the highly educated (Baxter 2002). A recent Swedish study found highly educated parents with an egalitarian attitude were most successful in encouraging children's participation in domestic tasks independent of gender (Evertsson 2006). Higher household income may also be associated with less domestic labor, because it can facilitate domestic outsourcing (Baxter 2002).

\section{Household Demand}

Parents, particularly mothers, may do more domestic labor in larger families and in households where there are young children (Craig and Mullan 2009). It is not clear whether there would be similar associations for young people. Some previous research suggests that children and young people in larger families do more housework than their counterparts in smaller families (Bianchi and 
Robinson 1997; Gager et al. 1999), but others have found no association (Wight et al. 2009). Having more young people in the household could reduce each young person's contribution, since there are more siblings to share it with. There are other aspects of household demand, such as higher domestic standards (which may mean all household members do more housework), or having a large house or grounds which generate more work for all, which our data cannot capture directly but which may be associated with both parents and young people's time in domestic activities.

\section{Race/Ethnicity}

Traditional 'ethnic' parents, particularly from Asian or Middle Eastern backgrounds, have been found to have different expectations than Anglo parents in regard to the timing of home leaving, contributions by young people to the family and household unpaid work (Mitchell 2004;

Brannen 1995; Boyd and Pryor 1989). In Australia, immigrant parents have more traditional divisions of domestic labor than the Australian born (Craig 2007). Domestic labor may therefore vary according to whether or not households are from a non-English speaking background (NESB).

\section{Methods}

We analyse data from the ABS Time Use Surveys (TUS), nationally representative surveys of the population of Australian households. To a detail level of 5 min intervals, over two consecutive days, all individuals aged 15 years and over in sampled households are required to complete a time-diary. This means we can analyse the time use of both young people and their parents in matched households. This is not possible in many countries, including the USA, which collect national time use data from only one respondent per household. We exclude three generation households and those in which there is more than one family unit, because if the young people are partnered or have children, or if there are other co-resident adults, domestic demand will be different. We use all three available years of the TUS (1992, 1997 and 2006). The final analytic sample is 1946 households; 5,512 diaries from 2,806 young people aged 15-34 years and 10,086 diaries from 5,129 parents. A sample description is given in Table 1.

\section{Table 1: Descriptive statistics (weighted)}

\begin{tabular}{|c|c|c|c|}
\hline \multicolumn{3}{|l|}{ Young person data $(n=2,806)$} & Per cent \\
\hline \multirow[t]{2}{*}{ Gender } & Male & & 57.3 \\
\hline & Female & & 42.7 \\
\hline \multirow[t]{3}{*}{ Age group } & $15-19$ & & 55.7 \\
\hline & $20-24$ & & 30.2 \\
\hline & $25-34$ & & 14.1 \\
\hline \multirow[t]{3}{*}{ Current main activity } & Studying & & 50.0 \\
\hline & Working & & 37.8 \\
\hline & $\begin{array}{l}\text { Not in employment, edu } \\
\text { (NEET) }\end{array}$ & ation or training & 12.2 \\
\hline Current main activity by age & $15-19$ & $20-24$ & $25-34$ \\
\hline Studying & 73.2 & 27.5 & 6.1 \\
\hline Working & 17.9 & 57.2 & 75.3 \\
\hline NEET & 8.9 & 15.3 & 18.6 \\
\hline \multicolumn{4}{|c|}{ Fathers' characteristics $(n=2,395)$} \\
\hline \multirow[t]{2}{*}{ Relationship status } & Single & & 3.1 \\
\hline & Partnered & & 96.9 \\
\hline \multirow[t]{2}{*}{ Employment status } & Employed full-time & & 81.2 \\
\hline & Not employed full-time & & 18.8 \\
\hline \multirow[t]{2}{*}{ Education level } & No tertiary degree & & 82.9 \\
\hline & Degree & & 17.1 \\
\hline \multicolumn{4}{|c|}{ Mothers' characteristics $(n=2,734)$} \\
\hline \multirow[t]{2}{*}{ Relationship status } & Single & & 15.4 \\
\hline & Partnered & & 84.6 \\
\hline Employment status & Employed full-time & & 33.8 \\
\hline
\end{tabular}




\begin{tabular}{|c|c|c|}
\hline \multirow{4}{*}{ Education level } & Employed part-time & 31.7 \\
\hline & Not employed & 34.5 \\
\hline & No tertiary degree & 87.0 \\
\hline & Degree & 13.0 \\
\hline \multicolumn{3}{|l|}{ Household data $(n=1,973) 13.0$} \\
\hline \multirow[t]{3}{*}{ Household type } & Single parent - mother only & 15.8 \\
\hline & Single parent - father only & 2.9 \\
\hline & Couple parents & 81.3 \\
\hline \multirow[t]{2}{*}{ Number of children $<15$ in household } & None & 78.3 \\
\hline & One or more & 21.7 \\
\hline \multirow[t]{2}{*}{ Number of young people in household } & One & 63.8 \\
\hline & Two or more & 36.2 \\
\hline \multirow[t]{2}{*}{ Main language spoken at home } & English & 90.3 \\
\hline & Language other than English & 9.7 \\
\hline \multirow[t]{3}{*}{ Survey year } & 1992 & 36.1 \\
\hline & 1997 & 34.4 \\
\hline & 2006 & 29.5 \\
\hline
\end{tabular}

\section{Dependent Variables}

Our interest is in domestic work (ABS 2006 TUS codes 400-499) which includes food preparation (e.g. cooking, clean-up, setting the table); laundry and cleaning (e.g. washing, ironing, sorting clothes, wet and dry housework); outdoor work (e.g. gardening, animal care, cleaning grounds, pool care); household maintenance (e.g. home improvements, making furniture and furnishings, car care); household management (e.g. paperwork, bills and budgeting, recycling and disposing of rubbish) and communication and travel associated with domestic work as well as the related activity of purchasing consumer goods (ABS 2006 TUS code 611 purchasing groceries, food etc.). We separately analyse the routine tasks of (1) food preparation, (2) laundry and cleaning, (3) the sum of non-routine activities (outdoor work, household maintenance, and household management), and (4) grocery shopping.

\section{Analysis Plan}

We use multivariate regression to examine associations between each type of domestic labor and young people's, parents' and household characteristics. Because gender is central to the performance of housework (Sayer 2005), and implicated in the pace of achieving transition to adulthood (Mahaffy 2004) and the likelihood of being co-resident with parents (Mitchell 2004), we run our models separately by gender for both generations.

The models control for variables associated with variation in domestic work, as identified above. We enter age of the young person (15-19 (omitted)/20-24/25-34). Young people aged 15-19 years are the base category because it is most age-appropriate for them to be living at home, still be studying and not be self-sufficient. As indicators of time availability, we enter the young person's current main activity (studying (omitted)/working/neither working nor studying). We also enter parent's employment status (mothers: employed full-time (omitted)/part-time/not employed; fathers: employed (omitted)/not employed or employed part-time). We do not use part-time employment as a separate category for fathers because the overwhelming majority of employed fathers have full-time status. Because family structure may impact on young people's domestic contribution and indirectly on parents' time availability we control for relationship status of parents (couple (omitted)/single).

As indicators of household resources, we enter equivalised household income (low/middle (omitted)/high). Equivalised income takes into account the number of people in the household. Household income groups were based on the full ABS samples across the survey years. The bottom three deciles were classified as low income, the top three as high income and the remainder as middle income. We enter mothers and fathers' education (no college degree (omitted)/college degree), as it could be related to both household resources and gender attitudes (Schoeni and Ross 2004; 
Baxter 2002). As indicators of household demand we enter the number of young people aged 1534 [1(omitted)/2 or more] and whether there are children aged under 15 years in the household [yes/no (omitted)]. We control for minutes per day (mpd) spent in each activity by others in the household because some households may have a large house or grounds (which our data cannot capture), or perform more/less of a given activity due to differing family standards. To capture ethnicity we enter whether the household is from a non-English speaking background [yes/no (omitted)] because these households may have more traditional gender ideology and household time allocation (Mitchell 2004). (There is no substantial Black or Hispanic population in Australia.) We enter survey year [1992 (omitted)/1997/2006] to control for societal change in domestic labor over time.

All multivariate models apply a generalised linear model using the Poisson-Gamma distribution with a logarithm link function. The Poisson distribution is a discrete distribution that arises when a number of activity episodes are counted. The gamma distribution is a continuous, right-skewed distribution that does not contain zeros. Compared to linear and Tobit models, the Poisson-Gamma model has theoretical and empirical advantages in analysing time use data when large numbers of respondents record no time (zero) in the activities considered (see Brown and Dunn 2011 for a full discussion). Tobit models in particular reject the null hypothesis too often (Stewart 2009; Marin-Galiano and Kunert 2006; Brown and Dunn 2011). All analyses were performed using R (R Development Core Team); the R libraries tweedie (Dunn 2006) and statmod (Smyth 2004) were used for PoissonGamma computations (e.g. computing the index of the Poisson-Gamma distributions). The R function svyglm was used to fit the Poisson-Gamma glm model. Two stage clustering (person within household and diary within person) was accounted for and data were weighted to ensure an even distribution of days of the week and to correct for potential non-response bias.

\section{Results}

A sample description is presented in Table 1. A higher proportion of co-resident young people is male than female (57\% vs. $43 \%$ ), and most who co-reside are teenagers (56\%), rather than aged 20-24 (30\%) or 30-34 (14\%). Half of the co-resident young people are studying, $38 \%$ are working, and $14 \%$ are neither working nor in education/training (NEET). The proportion of co-resident young people who are NEET is larger in older age groups (19\% of 25-34 year olds, $15 \%$ of 20-24 year olds, compared to $9 \%$ of 15-19 year olds), supporting research which suggests it is a factor in coresidence beyond the more normative teenage years (Settersten and Ray 2010).

\section{Amount, Frequency and Duration of Domestic Labor}

The Poisson-Gamma model can be separated into the component parts of the number and length of episodes which can be used to predict average episode frequency and duration for each person in the sample. Table 2 summarizes these data by gender and generation.

Differences between the genders' average daily time in indoor routine tasks primarily reflect differences in how often tasks were performed, not the duration of the episodes. For example, young women averaged $25 \mathrm{~min}$ in food preparation once every 1.5 days $(1 / 0.7)$, giving a daily average of $17 \mathrm{mpd}$. Young men averaged a similar $23 \mathrm{~min}$ per episode of food preparation, but they did it less often [once every 2.5 days (1/0.4)] so their daily average was only 9 min. Young people's time on laundry and cleaning showed the same trend. The same pattern was also broadly evident for mothers and fathers. That is, mothers' daily average time in indoor activities was considerably larger than fathers', with the differences resulting more from the frequency with which the activities were performed than from the duration of each episode (Table 2). In other words, when men do participate in indoor domestic work, they do a similar amount to women; however, they participate much less often. 
Table 2: Predicted average number of episodes per day, average length of episodes and average time per day in all activities considered

\begin{tabular}{|c|c|c|c|c|c|c|}
\hline & $\begin{array}{l}\text { Mean } \\
\text { episodes per } \\
\text { day }\end{array}$ & $\begin{array}{l}\text { Mean } \\
\text { episode } \\
\text { length } \\
\end{array}$ & $\begin{array}{l}\text { Mean } \\
\text { minutes per } \\
\text { day }\end{array}$ & $\begin{array}{l}\text { Mean } \\
\text { episodes per } \\
\text { day }\end{array}$ & $\begin{array}{l}\text { Mean } \\
\text { episode } \\
\text { length } \\
\end{array}$ & $\begin{array}{l}\text { Mean } \\
\text { minutes per } \\
\text { day }\end{array}$ \\
\hline Young people & \multicolumn{3}{|c|}{ Women } & \multicolumn{3}{|c|}{ Men } \\
\hline Food preparation & 0.7 & 25 & 17 & 0.4 & 23 & 9 \\
\hline $\begin{array}{l}\text { Laundry and } \\
\text { cleaning }\end{array}$ & 0.5 & 34 & 17 & 0.2 & 37 & 7 \\
\hline Grocery shopping & 0.3 & 17 & 5 & 0.2 & 14 & 3 \\
\hline Non-routine tasks & 0.4 & 32 & 13 & 0.3 & 52 & 16 \\
\hline Parents & \multicolumn{3}{|c|}{ Mothers } & \multicolumn{3}{|c|}{ Fathers } \\
\hline Food preparation & 2.4 & 35 & 84 & 0.8 & 30 & 24 \\
\hline $\begin{array}{l}\text { Laundry and } \\
\text { cleaning }\end{array}$ & 1.8 & 51 & 92 & 0.3 & 46 & 14 \\
\hline Grocery shopping & 0.4 & 27 & 11 & 0.3 & 18 & 5 \\
\hline Non-routine tasks & 1.3 & 35 & 45 & 0.9 & 65 & 59 \\
\hline
\end{tabular}

Notes: Averages derived from Poisson-Gamma models (model details in Tables 3 and 4).

With respect to non-routine tasks, young women and men averaged a similar amount of time overall. However, while young men did non-routine activities less often than young women, when they did do them, they spent a longer average period of time. For parents, fathers averaged more time on nonroutine tasks than mothers. Fathers did non-routine tasks less often than mothers did, but as with young people the duration of the episodes was greater for men than for women. Grocery shopping was relatively gender neutral, especially for the younger generation, who spent little time on it in any event.

Young people averaged much less domestic labor across all categories than parents, because they did them both less frequently and for shorter periods each time. The smallest generation differences were in grocery shopping, and with the exception of non-routine tasks, average differences between young men and fathers were less pronounced than those between young women and mothers. As expected, mothers did routine tasks more frequently than their partners or children. Indeed, mothers did all forms of domestic labor we considered, including non-routine tasks, more frequently than fathers or young people.

We next identify characteristics of co-resident households, parents and young people which may be associated with variations from the average patterns noted above.

\section{Factors Associated with Time Spent by Parents and Young People in Domestic Activities}

Poisson-Gamma models use a log-link. In order to make valid interpretations it is necessary to exponentiate the beta coefficients. To interpret the intercept, $\exp (\beta 0)$ is taken. The formula to calculate the difference between any given beta coefficient and the intercept $(\beta 0)$ is $\exp (\beta 0+\beta \mathrm{x})-\exp (\beta 0)$. To assist interpretation, these calculations have been made and the results are presented in Table 3 (indoor routine tasks) and Table 4 (non-routine tasks and grocery shopping). The original Poisson-Gamma parameter estimates are available on request.

We expected that young people's gender would matter to parental time. We found it did, but applied only to mothers and only for some domestic activities. Mothers were predicted to spend 5 mpd more in non-routine tasks, and $5 \mathrm{mpd}$ less in food preparation, if the young person was female. Young people's gender had no association with fathers' time.

Age was significantly associated with the domestic time of young people. Young women in the age groups 20-24 and 25-34 both did more food preparation than young women aged 15-19 (5 and $10 \mathrm{mpd}$, respectively), and young men aged 25-34 did more food preparation (6 mpd) and more 
grocery shopping (4 mpd) than young men in the younger age groups. However, young people's age showed no corresponding negative association with parents' domestic labor time. Indeed mothers of young people aged 25-34 averaged $9 \mathrm{mpd}$ more in food preparation than mothers with younger children. Together with the finding for 25-34 year olds above this implies that these households spend more time in food preparation in total.

Young people's time availability was associated with the time they themselves spent in most domestic tasks. Compared to those studying, if their 'current main activity' was neither employment nor education/training (NEET), both young women and men spent more time preparing food (females $8 \mathrm{mpd}$; males $4 \mathrm{mpd}$ ), doing the laundry or cleaning (females $14 \mathrm{mpd}$; males $8 \mathrm{mpd}$ ) and non-routine domestic tasks (females $9 \mathrm{mpd}$; males $13 \mathrm{mpd}$ ). There was no association between young people's main activity and grocery shopping. Parents' domestic labor was largely found not to be associated with young people's time availability, with the single exception that mothers with children who were NEET spent 10 mpd less in food preparation than mothers whose child was studying. This exception is substantial, however, amounting to more than an hour per week.

Parents' time availability: For mothers, full-time employment (compared to not working) was associated with less time in indoor routine domestic tasks (41 mpd less food preparation and $47 \mathrm{mpd}$ less laundry/cleaning). The equivalent differences for fathers (albeit with non-full-time-working fathers including those working part-time) were 13 and $10 \mathrm{mpd}$, respectively. For non-routine tasks, fathers not working full-time spent $33 \mathrm{mpd}$ less than fathers working full-time, while the difference between mothers working full-time, compared to those not working, was $20 \mathrm{mpd}$ less. Non-full-timeworking fathers averaged marginally $(2 \mathrm{mpd})$ more grocery shopping than those who worked fulltime.

With regard to cross-generation effects, no associations were found between fathers' time in any domestic activity and children's current main activity. Nor did fathers' time availability show much association with young peoples' domestic work. The exceptions were significant but substantively negligible $(<1 \mathrm{mpd})$ associations between paternal employment and young people's time in grocery shopping and non-routine tasks. Mothers' time availability was associated with somewhat more time variation in the younger generation: sons spent an average $3 \mathrm{mpd}$ more on non-routine tasks if their mother was not in the workforce rather than employed full-time. With mothers working part-time rather than full-time, daughters spent less time in non-routine tasks $(5 \mathrm{mpd})$ while sons spent more (5 mpd).

Family structure: In single-rather than two-parent households young women spent more time grocery shopping (4 mpd) and young men spent more time in food preparation ( $3 \mathrm{mpd}$ ) and nonroutine activities ( $5 \mathrm{mpd}$ ). Conversely, single mothers and fathers both spent less time grocery shopping (mothers $4 \mathrm{mpd}$, fathers $3 \mathrm{mpd}$ ), than married parents. Compared to their married counterparts, single mothers spent less time on food preparation $(18 \mathrm{mpd})$ and laundry/cleaning (26 mpd) and single fathers more time on these activities ( 7 and $11 \mathrm{mpd}$ respectively).

Parents' education: Mothers with a tertiary degree spent less time $(13 \mathrm{mpd})$ doing the laundry and cleaning compared to those without a degree, but, no less time in other tasks. For fathers, having a degree was not associated with more domestic work. Parents' education also had almost no associations with young peoples' time in any form of domestic labor. The only exception was a positive but substantively negligible relationship $(\sim 1 \mathrm{mpd})$ between fathers having a degree and children's grocery shopping. Thus, there was little indication that liberal household gender attitudes linked to parents' higher education affected young adult children's housework; associations were concentrated in the older generation. Although they predominantly involved educated women doing less rather than educated men doing more there was a positive association between mothers' higher education and fathers' food preparation $(6 \mathrm{mpd})$. This aligns with a recent study showing that higher 
levels of male childcare is associated with their wives', rather than their own, higher education (Gauthier and DeGusti 2012).

Household demand showed no relationship with young peoples' domestic labour. The presence of children under 15 was associated with mothers spending very slightly more time $(1.2 \mathrm{mpd})$ in nonroutine activities. Both mothers and fathers did more laundry and cleaning when there were $2+$ young people in the household ( 9 and $3 \mathrm{mpd}$, respectively). We controlled for time that other household members spent in domestic tasks as a partial indicator of factors which our data cannot capture, including differing family standards and size of house or grounds. Few associations were found, all substantively negligible.

Ethnicity: We used non-English speaking background as an indirect indicator of traditional gender ideology and found that it was related to more time cooking by young women $(7 \mathrm{mpd})$ and mothers $(11 \mathrm{mpd})$ and less time $(11 \mathrm{mpd})$ in non-routine tasks by mothers. Unexpectedly, mothers from a nonEnglish speaking background also spent less time than other mothers on laundry and cleaning $(15 \mathrm{mpd})$, and there were no associations between ethnicity and any type of domestic work for either fathers or young men.

Survey year: Fathers spent nearly 50 \% more time (7 mpd) preparing food in 2006 than in 1992. Fathers' time in laundry and cleaning increased by $5 \mathrm{mpd}$ from a base of $9 \mathrm{mpd}$ in 1992 and grocery shopping by $2 \mathrm{mpd}$ from a base of $5 \mathrm{mpd}$ in 1992. Conversely, compared to 1992, mothers spent an average of $12 \mathrm{mpd}$ less in 2006 than in 1992 doing laundry and cleaning. Young women averaged less time in food preparation $(3 \mathrm{mpd})$ and laundry and cleaning $(6 \mathrm{mpd})$ and more on grocery shopping $(<1 \mathrm{mpd})$, while young men averaged more food preparation $(2 \mathrm{mpd})$ and less non-routine work (3 mpd), in 2006 than in 1992.

\section{Discussion}

Scholars argue that work-family issues, including divisions in domestic labor, should be approached from a household rather than an individual perspective (Bianchi and Milkie 2010; Cooke and Baxter 2010). A significant minority of households are comprised of young adults co-resident with their parents, yet to our knowledge no previous research has investigated domestic labor in these households from the perspective of both generations (Mitchell 2006). Using Australian time use data from matched household members, this paper began that inquiry, exploring patterns in and correlates of the domestic work of co-resident parents and young people aged 15-34.

Previous research has established that men's domestic labor is often a matter of choice, while women's is obligatory and routine (McMahon 1999; Dempsey 1997). Women not only do more domestic labor overall, but they also do it more often, with consequent impacts on how they (can) structure their time (Craig 2007). Housework and how it is divided within families are thus important indicators of equity and quality of life. Results showed that parents and young people's time in domestic tasks differed in both frequency and duration. Parents did domestic tasks more often, and for longer each time, than young people of the same gender. Mothers did most tasks more frequently, and for longer, than either fathers or young people, suggesting that 'routine' tasks in particular are regular daily responsibilities for mothers only, with both fathers and young people of both genders much more occasional participants. Notwithstanding, young women did domestic labor tasks more frequently than young men, and with the exception of non-routine tasks, about as frequently as fathers. While these findings support the extensive literature demonstrating the gendered nature of domestic work, it is interesting to note that when men (fathers and young people) did participate in routine tasks especially, they did a similar amount to their counterparts (mothers and young women).

The main focus of the paper was identifying the factors that predict more or less domestic work among young people and co-resident parents, with a particular interest in identifying characteristics 
that affected both generations. Since age norms strongly influence parental expectations of young people (Mahaffy 2004; Settersten et al. 2005), we anticipated those co-resident at older ages (particularly over 25) would contribute most to the running of the household. For both young men and young women, food preparation was higher the older they were, and 25-34 year olds did more cleaning and laundry and non-routine activities than younger people. However, we found little evidence that this increased time by older young people relieved their parents of domestic work, with positive associations between parental food preparation and having a 25-34 year old (mothers) or a 20-24 year old (fathers) co-resident. It could be that such activities become more pleasurable as children grow older, and all members of families with an interest in food preparation do more of it, perhaps cooking together. Alternatively, when young people are older, household members may be increasingly cooking for themselves but not for others in the family, thus doubling up on household effort. In any event, the implication is that older young peoples' domestic labor does not save parents' time.

Similarly, young people's time availability through their employment/student status had more associations with their own domestic time than with their parents'. An important exception was that having a NEET child was associated with less food preparation for mothers, suggesting that children who are neither working nor studying substitute their cooking time for mothers'. This and the finding that mothers of daughters do less food preparation were the only indications that any characteristics of co-resident young people might be associated with less domestic labor time for mothers, however.

On the other hand, there were some parental characteristics that were associated with apparent tradeoffs between parents and young people. Mothers' time availability was associated with housework variation in the younger generation: sons spent an average $3 \mathrm{mpd}$ more on non-routine tasks if their mother was not in the workforce rather than employed full-time. With mothers working part-time rather than full-time, daughters spent less time in non-routine tasks while sons spent more. Fathers' time availability showed only negligible associations with young peoples' domestic work. Overall, young people's domestic labor time was slightly more sensitive to fathers' than to mothers' characteristics. This is perhaps because both fathers and young people's domestic contributions are more contingent than mothers, for whom domestic labor time is comparatively inelastic.

In single, rather than two-parent, households young women spent more time grocery shopping and young men spent more time in food preparation and non-routine activities. Conversely, single parents both spent less time grocery shopping, single mothers spent less time on food preparation and laundry/cleaning. Parents' education also had almost no associations with young peoples' time in any form of domestic labor.

In line with previous research findings that adult women's housework is more responsive to family characteristics than men's (see for example Sayer 2005), we expected the same would also apply to co-resident young women. In the event, evidence to support this was weak. In an important exception, non-English speaking background, related to household gender ideology, affected young women but not young men. Otherwise, most household or parental characteristics that predicted variation did so for young people of both genders (albeit with different effect sizes). That is, although gender differences in absolute amount of time were wide, factors associated with divergence from average patterns were broadly comparable for young men and young women.

Overall we found few indications that young people's domestic labor might save parents time. Of the several significant direct associations between parents' and young people's time in specific domestic activities, most were positive rather than negative. Again it may be that parents and children are doing the activities together, or that young people are doing the activities for their own self-maintenance rather than for others in the family. 
There was some evidence of a trend towards more gender equality in task type. Fathers did more food preparation, laundry/cleaning and grocery shopping, young men more food preparation, mothers less laundry/cleaning and young women less food preparation in 2006 than their counterparts in earlier surveys. These results build on previous research, which finds that over time women are doing rather less and men rather more domestic labor (Sayer 2005; Bianchi and Milkie 2010). That effect sizes were larger in the elder generation may mean that more of the average change over time in men's domestic contribution is driven by practical demands associated with being a husband and father than from changing expectations of younger men within their families of origin.

This study was subject to a number of limitations. The data are cross-sectional, which limited study of young people's maturation. To disentangle age and cohort effects would ideally require time use panel data, but unfortunately, none are unavailable. More broadly, our analyses could identify correlations only, not causal effects, which may run in either direction. A further limitation is that selection effects may affect our findings. Young people who live at home may be those who are less able or less inclined to take on domestic responsibility, This possibility is reinforced by the fact that in our sample a relatively high proportion of young people over 20 years old were NEET. Future research could usefully compare young people's domestic labor across different types of living arrangement, and build on the information this paper has contributed on the patterns and correlates of domestic labor in households in which young people aged 15-34 are co-resident with their parents.

\section{References}

ABS (2013). Australian social trends 2013 catalogue no. 4102.0. Canberra: Australian Bureau of Statistics.

Baxter, J. (2002). Patterns of change and stability in the gender division of household labour in Australia, 19961997. Journal of Sociology, 38(4), 399-424.

Bell, L., Burtless, G., Gornick, J., \& Smeeding, T. (2007). A cross-national survey of trends in the transition to economic independence. In S. H. Danziger \& C. Rouse (Eds.), The price of independence: The economics of early adulthood (pp. 27-55). New York: Russell Sage Foundation Press.

Bianchi, S., \& Milkie, M. (2010). Work and family research in the first decade of the 21 st century. Journal of Marriage and Family, 72(3), 705-725.

Bianchi, S., \& Robinson, J. (1997). What did you do today? Children's use of time, family composition and the acquisition of social capital. Journal of Marriage and the Family, 59(2), 332-334.

Bonke, J. (2010). Children's housework: Are girls more active than boys? Electronic International Journal of Time Use Research 7(1), 1-16.

Boyd, M., \& Pryor, E. T. (1989). The cluttered nest: The living arrangements of young Canadian adults. The Canadian Journal of Sociology, 14, 461-477.

Brannen, J. (1995). Young people and their contribution to household work. Sociology, 29(2), 317-338.

Brown, J., \& Dunn, P. (2011). Comparisons of tobit, linear regression and Poisson-Gamma regression models: An application of time use data. Sociological Methods and Research, 40(3), 511-535.

Cobb-Clark, D. (2008). Leaving home: What economics has to say about the living arrangements of young Australians. Australian Economic Review, 41(2), 160-176.

Coltrane, S. (2007). Fatherhood, gender and work-family policies. In E. O. Wright (Ed.), Real utopias. Madison, WI: University of Wisconsin.

Cooke, L. P., \& Baxter, J. (2010). 'Families' in international context: Comparing institutional effects across western societies. Journal of Marriage and Family, 72, 516-536.

Craig, L. (2006). The money or the care? A comparison of couple and sole parent households' time allocation to work and children. Australian Journal of Social Issues, 40(4), 521-540.

Craig, L. (2007). Is there really a "second shift", and if so, who does it? A time-diary investigation. Feminist Review, 86(1), 149-170. 
Craig, L., \& Bittman, M. (2008). The effect of children on adults' time-use: An analysis of the incremental time costs of children in Australia. Feminist Economics, 14(2), 57-85.

Craig, L., \& Mullan, K. (2009). The policeman and the part-time sales assistant: Household labour supply, family time and subjective time pressure in Australia 1997-2006. Journal of Comparative Family Studies, 40(4), 545-560.

Craig, L., \& Mullan, K. (2011). Lone and couple mothers' childcare time within context in four countries. European Sociological Review, 28(4), 512-526.

Craig, L., \& Sawrikar, P. (2009). Work and family: how does the (gender) balance change as children grow? Gender, Work and Organisation, 16(6), 684-709.

de Vaus, D. (2004). Diversity and change in Australian families: Statistical profiles. Melbourne: Australian Institute of Family Studies.

Dempsey, K. (1997). Inequalities in marriage. Melbourne: Oxford University Press.

Dodson, L., \& Dickert, J. (2004). Girls' family labor in low-income households: A decade of qualitative research. Journal of Marriage and Family, 66(2), 318-332.

Dunn, P. (2006). tweedie: Tweedie exponential family models. RPackage Version, 2(1), 7.

\section{Google Scholar}

Erikson, E. H. (1959). Identity and the life circle. New York: International University Press.

Evertsson, M. (2006). The reproduction of gender: Housework and attitudes towards gender equality in the home among Swedish boys and girls. The British Journal of Sociology, 57(3), 415-436.

Fingerman, K., Miller, L., Birditt, K., \& Zarit, S. (2009). Giving to the good and the needy: Parental support of grown children. Journal of Marriage and Family, 71(5), 1220-1233.

Furlong, A. (2009). Changing contexts, changing lives. In A. Furlong (Ed.), Handbook of youth and young adulthood: New perspective and agendas. New York: Routledge.

Furstenberg, F., Kennedy, S., McLoyd, V., Rumbaut, R., \& Settersten, R. (2004). Growing up is harder to do. Contexts, 3(3), 33-41.

Gager, C. T., Cooney, T. M., \& Call, K. T. (1999). The effects of family characteristics and time use on teenagers' household labor. Journal of Marriage and Family, 61(4), 982-994.

Gauthier, A., \& DeGusti, B. (2012). The time allocation to children by parents in Europe. International Sociology, 27(6), 827-845.

Gauthier, A., \& Furstenberg, F. (2002). The transition to adulthood: A time use perspective. The Annals of the American Academy of Political and Social Science, 580 (March), 153-171.

Greenfield, E., \& Marks, N. (2006). Linked lives: Adult children's problems and their parents' psychological and relational well-being. Journal of Marriage and Family, 68(2), 442-454.

Hartnett, C. S., Furstenberg, F. F., Birditt, K. S., \& Fingerman, K. L. (2012). Parental support during young adulthood: Why does assistance decline with age? Journal of Family Issues,

Hendry, L. B., \& Kloep, M. (2012). Adolescence and adulthood: Transitions and transformations. New York: Palgrave Macmillan.

Kloep, M., \& Hendry, L. B. (2010). Letting go or holding on? Parents' perceptions of their relationships with their children during emerging adulthood. British Journal of Developmental Psychology, 28(4), 817 834.

Larson, R. W., \& Verma, S. (1999). How children and adolescents spend time across the world: Work, play, and developmental opportunities. Psychological Bulletin, 125(6), 701-736.

Mahaffy, K. A. (2004). Gender. Race, class, and the transition to adulthood: A critical review of the literature sociological studies of children and youth, 9, 15-47.

Mandic, S. (2008). Home-leaving and its structural determinants in western and eastern Europe: An exploratory study. Housing Studies, 23(4), 615-637. 
Manke, B., Seery, B. L., Crouter, A. C., \& McHale, S. M. (1994). The three corners of domestic labor: Mothers', fathers', and children's weekday and weekend housework. Journal of Marriage and Family, 56(3), 657-668.

Marin-Galiano, M., \& Kunert, J. (2006). Comparison of ANOVA with the Tobit model for analysing sensory data. Food Quality and Preference, 17(3-4), 209-218.

McMahon, A. (1999). Taking care of men: Sexual politics in the public mind. Cambridge: Cambridge University Press.

Miller, P. (2012). Do australian teenagers work? Why we should care. Feminist Economics.

Miller, P., \& Bowd, J. (2010). Do Australian teenagers contribute to household work? Family Matters, 85, 6876.

Mitchell, B. (2004). Home, but not alone: Socio-cultural and economic aspects of canadian young adults sharing parental households. Atlantis, 28(2), 115-125.

Mitchell, B. (2006). The boomerang age from childhood to adulthood: Emergent trends and issues for aging families. Canadian Studies in Population, 33(2), 155-178.

Raley, K., Crissey, S., \& Muller, C. (2007). Of sex and romance: Late adolescent relationships and young adult union formation. Journal of Marriage and Family, 69(5), 1210-1226.

Romich, J. L. (2007). Sharing the work: Mother-child relationships and household management. The Journal of Early Adolescence, 27(2), 192-222.

Salman Rizavi, S., \& Sofer, C. (2010). The third partner in the household: an analysis of children's household work. Paper presented at the 27th Journées de Microéconomie, University of Angers, France, 3-4 June.

Sayer, L. (2005). Gender, time and inequality: Trends in women's and men's paid work, unpaid work and free time. Social Forces, 84(1), 285-303.

Schoeni, R., \& Ross, K. (2004). Material assistance received from families during the transition to adulthood. In R. Settersten, F. Furstenberg, \& R. Rumbaut (Eds.), On the frontier of adulthood: Theory, research, and public policy. Chicago: University of Chicago Press.

Settersten, R., Furstenberg, F., \& Rumbaut, R. (Eds.). (2005). On the frontier of adulthood: Theory, research, and public policy. Chicago: The University of Chicago Press.

Settersten, R., \& Hagestad, G. O. (1996). What's the latest? Cultural age deadlines for family transitions. The Gerontologist, 36, 178-188.

Settersten, R., \& Ray, B. (2010). What's going on with young people today? The long and twisting path to adulthood. The Future of Children, 20(1), 19-41.

Smyth, G. (2004). statmod: Statistical modelling. R package Version, 1(4), 17.

Stewart, J. (2009). Tobit or not tobit? BLS working paper no. 432. Washington, DC: Bureau of Labor Statistics.

Sullivan, O. (1997). Time waits for no (wo)man: An investigation of the gendered experience of domestic time. Sociology, 31(2), 221-239.

Swartz, T. T., Kim, M., Uno, M., Mortimer, J., \& O’Brien, K. B. (2011). Safety nets and scaffolds: Parental support in the transition to adulthood. Journal of Marriage and Family, 73(2), 414-429.

Tanner, J., \& Arnett, J. (2009). The emergence of 'emerging adulthood'. In A. Furlong (Ed.), Handbook of youth and young adulthood (pp. 39-45). New York: Routledge.

U.S. Census Bureau. (2001). America's families and living arrangements: 2001. Table A2: Family status and household relationships of people 15 years and over, by marital status, age, sex, race and hispanic origin. Washington, DC: United States Census Bureau.

U.S. Census Bureau. (2011). America's families and living arrangements: 2011. Table A2: Family status and household relationship of people 15 years and over, by marital status, age and sex. Washington DC: United States Census Bureau. 
Veevers, J. E., \& Mitchell, B. A. (1998). Intergenerational exchanges and perceptions of support within "boomerang kid" family environments. The International Journal of Aging and Human Development, 46(2), 91-108.

Wight, V., Price, J., Bianchi, S., \& Hunt, B. (2009). The time use of teenagers. Social Science Research, 38(4), 792-809. 
Table 3: Poisson-Gamma regression of parents and young people's minutes per day in food preparation and laundry/cleaning

\begin{tabular}{|c|c|c|c|c|c|c|c|c|}
\hline & \multicolumn{2}{|c|}{ Mothers } & \multicolumn{2}{|c|}{ Fathers } & \multicolumn{2}{|c|}{ Young women } & \multicolumn{2}{|c|}{ Young men } \\
\hline & Food prep & $\begin{array}{l}\text { Laundry/ } \\
\text { cleaning }\end{array}$ & $\begin{array}{l}\text { Food } \\
\text { prep }\end{array}$ & $\begin{array}{l}\text { Laundry/ } \\
\text { cleaning }\end{array}$ & $\begin{array}{l}\text { Food } \\
\text { prep }\end{array}$ & $\begin{array}{l}\text { Laundry/ } \\
\text { cleaning }\end{array}$ & $\begin{array}{l}\text { Food } \\
\text { prep }\end{array}$ & $\begin{array}{l}\text { Laundry/ } \\
\text { cleaning }\end{array}$ \\
\hline \multicolumn{9}{|c|}{ Young people's characteristics } \\
\hline Female & $-5.28 * *$ & -0.57 & -0.99 & -1.60 & & & & \\
\hline \multicolumn{9}{|l|}{ Age } \\
\hline $15-19$ & 3.99 & & & & & & & \\
\hline $20-24$ & & -0.99 & $3.22 *$ & 0.79 & $4.85^{*}$ & 3.94 & 0.38 & -1.51 \\
\hline $25-34$ & $8.51 *$ & -5.74 & 0.34 & 1.74 & $9.87 *$ & 3.95 & $5.51 *$ & 5.07 \\
\hline \multicolumn{9}{|l|}{ Main activity } \\
\hline \multicolumn{9}{|l|}{ Studying } \\
\hline Paid work & -3.19 & 2.71 & -0.51 & -0.41 & $-4.15^{*}$ & $-3.78 *$ & $-1.63 *$ & -0.07 \\
\hline NEET & $-10.12 * * *$ & -5.28 & -2.47 & -2.28 & $8.40 * *$ & $13.71 * * *$ & $3.68 * *$ & $7.52 *$ \\
\hline Time in activity & 0.04 & -0.10 & 0.01 & 0.00 & & & & \\
\hline \multicolumn{9}{|c|}{ Parents' characteristics } \\
\hline \multicolumn{9}{|l|}{ Father } \\
\hline Time in activity & -0.06 & $-0.10^{*}$ & & & -0.02 & $0.04 *$ & $0.03 * *$ & 0.01 \\
\hline $\begin{array}{l}\text { Has a tertiary } \\
\text { degree }\end{array}$ & 0.26 & 0.08 & 1.73 & -1.27 & -0.96 & -1.66 & 1.23 & 5.42 \\
\hline \multicolumn{9}{|l|}{$\begin{array}{l}\text { Employment } \\
\text { status }\end{array}$} \\
\hline \multicolumn{9}{|l|}{ Fulltime } \\
\hline Other & $7.24 *$ & $17.72 * *$ & $13.23 * * *$ & $10.15^{* * *}$ & -1.86 & -0.62 & -1.07 & -0.25 \\
\hline \multicolumn{9}{|l|}{ Mother } \\
\hline Time in activity & & & -0.02 & -0.01 & 0.01 & -0.01 & 0.00 & 0.00 \\
\hline $\begin{array}{l}\text { Has a tertiary } \\
\text { degree }\end{array}$ & -1.28 & $-12.85^{*}$ & $5.62 * *$ & 3.15 & 0.48 & 0.50 & -1.00 & -2.97 \\
\hline \multicolumn{9}{|l|}{$\begin{array}{l}\text { Employment } \\
\text { status }\end{array}$} \\
\hline \multicolumn{9}{|l|}{ Fulltime } \\
\hline Part-time & $20.02 * * *$ & $30.86^{* * *}$ & -1.67 & 1.12 & -1.30 & 0.87 & -0.53 & 0.06 \\
\hline Not emp'd & $41.44 * * *$ & $47.34 * * *$ & -0.66 & 0.41 & -1.53 & -0.93 & -0.24 & 2.36 \\
\hline \multicolumn{9}{|c|}{ Household characteristics } \\
\hline Single parent & $-17.51 * * *$ & $-26.26 * * *$ & $7.46^{*}$ & $10.88 * *$ & 2.65 & 1.80 & $3.32 *$ & -1.47 \\
\hline Child aged $0-14$ & 0.90 & 2.58 & 4.10 & 1.11 & -0.41 & 2.42 & 0.38 & 0.41 \\
\hline $2+$ young people & 1.14 & $8.62 * *$ & 0.00 & $3.46^{*}$ & -0.40 & -0.15 & 0.35 & -2.38 \\
\hline NESB & $11.16^{* * *}$ & $-14.50 * * *$ & -3.85 & -2.03 & $6.98 *$ & 1.82 & -0.06 & -3.04 \\
\hline \multicolumn{9}{|l|}{ Survey year } \\
\hline \multicolumn{9}{|l|}{1992} \\
\hline 1997 & 0.61 & -1.79 & $5.86^{* *}$ & 2.98 & -1.92 & 1.02 & 1.32 & -1.01 \\
\hline 2006 & 0.60 & $-11.92 * * *$ & $7.23 * * *$ & $4.87 *$ & $-3.43 *$ & $-6.04 * * *$ & $2.43 *$ & -1.41 \\
\hline Intercept & 64.42 & $78.84 * * *$ & $17.11^{* * *}$ & $9.24 * * *$ & $19.34 * * *$ & $17.36^{* * *}$ & $6.81 * * *$ & $8.37 * * *$ \\
\hline $\begin{array}{l}\text { No. of } \\
\text { persons/diaries }\end{array}$ & \multicolumn{2}{|c|}{$2,734 / 5,372$} & \multicolumn{2}{|c|}{$2,395 / 4,714$} & \multicolumn{2}{|c|}{$1,288 / 2,534$} & \multicolumn{2}{|c|}{$1,518 / 2,978$} \\
\hline
\end{tabular}


Table 4: Poisson-Gamma regression of parents and young people's minutes per day in non-routine domestic tasks and grocery shopping

\begin{tabular}{|c|c|c|c|c|c|c|c|c|}
\hline & \multicolumn{2}{|c|}{ Mothers } & \multicolumn{2}{|c|}{ Fathers } & \multicolumn{2}{|c|}{ Young women } & \multicolumn{2}{|c|}{ Young men } \\
\hline & $\begin{array}{l}\begin{array}{l}\text { Non- } \\
\text { routine }\end{array} \\
\end{array}$ & Groceries & $\begin{array}{l}\begin{array}{l}\text { Non- } \\
\text { routine }\end{array} \\
\end{array}$ & Groceries & $\begin{array}{l}\begin{array}{l}\text { Non- } \\
\text { routine }\end{array} \\
\end{array}$ & Groceries & $\begin{array}{l}\begin{array}{l}\text { Non- } \\
\text { routine }\end{array} \\
\end{array}$ & Groceries \\
\hline \multicolumn{9}{|c|}{ Young people's characteristics } \\
\hline Female & $4.96^{* *}$ & -0.17 & 2.96 & -0.46 & & & & \\
\hline \multicolumn{9}{|l|}{ Age } \\
\hline \multicolumn{9}{|l|}{ 15-19 } \\
\hline $20-24$ & -0.26 & -0.20 & 3.83 & 0.48 & 5.12 & 0.10 & -0.43 & 0.22 \\
\hline $25-34$ & -2.99 & -1.46 & -1.50 & 1.78 & $4.12 *$ & -0.25 & $4.41 *$ & 0.29 \\
\hline \multicolumn{9}{|l|}{ Main activity } \\
\hline \multicolumn{9}{|l|}{ Studying } \\
\hline Paid work & -1.00 & 0.12 & 5.05 & -0.31 & -2.41 & $1.70 * *$ & 1.97 & 0.09 \\
\hline NEET & -0.05 & 0.58 & 6.37 & -0.51 & $9.46 * *$ & 0.50 & $12.51 * * *$ & 0.33 \\
\hline $\begin{array}{l}\text { Time in } \\
\text { activity }\end{array}$ & 0.01 & 0.01 & 0.09 & -0.01 & & & & \\
\hline \multicolumn{9}{|c|}{ Parents' characteristics } \\
\hline \multicolumn{9}{|l|}{ Father } \\
\hline $\begin{array}{l}\text { Time in } \\
\text { activity }\end{array}$ & -0.04 & -0.01 & & & $0.02 * * *$ & $0.05 * * *$ & -0.03 & 0.00 \\
\hline \multicolumn{9}{|l|}{$\begin{array}{l}\text { Has a tertiary } \\
\text { degree }\end{array}$} \\
\hline \multicolumn{9}{|l|}{$\begin{array}{l}\text { Employment } \\
\text { status }\end{array}$} \\
\hline \multicolumn{9}{|l|}{ Fulltime } \\
\hline Other & -3.58 & -1.79 & $32.94 * * *$ & $2.27 *$ & -1.98 & $-0.88 *$ & -1.51 & $0.98 * *$ \\
\hline \multicolumn{9}{|l|}{ Mother } \\
\hline $\begin{array}{l}\text { Time in } \\
\text { activity }\end{array}$ & & & 0.04 & -0.01 & $0.05^{* * *}$ & $-0.03 * * *$ & $0.01 *$ & $0.01 * * *$ \\
\hline $\begin{array}{l}\text { Has a tertiary } \\
\text { degree }\end{array}$ & 0.67 & -0.45 & 4.51 & 1.41 & -0.65 & -0.09 & 0.24 & 0.41 \\
\hline \multicolumn{9}{|l|}{$\begin{array}{l}\text { Employment } \\
\text { status }\end{array}$} \\
\hline \multicolumn{9}{|l|}{ Fulltime } \\
\hline Part-time & $17.85 * * *$ & 2.09 & 4.21 & 0.17 & $-4.57 * *$ & 0.30 & $4.47 * *$ & 0.28 \\
\hline Not emp'd & $19.94 * * *$ & 2.16 & 5.54 & 1.51 & -3.04 & 0.04 & $3.13^{*}$ & -0.12 \\
\hline \multicolumn{9}{|c|}{ Household characteristics } \\
\hline Single parent & & $-4.78 *$ & -7.45 & $-2.78 * *$ & 1.93 & $3.98 * * *$ & $4.98 *$ & 0.11 \\
\hline $\begin{array}{l}\text { Child aged } 0- \\
14\end{array}$ & $1.21 *$ & 0.43 & -1.94 & -0.57 & 1.82 & 0.22 & 0.03 & 0.14 \\
\hline $\begin{array}{l}2+\text { young } \\
\text { people }\end{array}$ & 2.56 & -1.47 & 1.65 & -0.66 & -2.51 & -0.85 & 0.90 & 0.06 \\
\hline NESB & $-10.60 * * *$ & -2.47 & -3.93 & -0.81 & -3.37 & -0.20 & 2.72 & 0.22 \\
\hline \multicolumn{9}{|l|}{ Survey year } \\
\hline \multicolumn{9}{|l|}{1992} \\
\hline 1997 & 2.66 & -0.72 & -5.87 & 0.83 & 2.89 & 0.06 & 0.05 & 0.40 \\
\hline 2006 & 2.00 & -0.60 & -6.70 & $2.05^{*}$ & 1.13 & $1.34 *$ & $-2.54 *$ & 0.43 \\
\hline Intercept & $31.49 * * *$ & $11.74 * * *$ & $44.59 * * *$ & $4.52 * * *$ & $11.68^{* * *}$ & $2.96^{* * *}$ & $8.59 * * *$ & 1.22 \\
\hline $\begin{array}{l}\text { No. of } \\
\text { persons/diaries }\end{array}$ & \multicolumn{2}{|c|}{$2,734 / 5,372$} & \multicolumn{2}{|c|}{$2,395 / 4,714$} & \multicolumn{2}{|c|}{$1,288 / 2,534$} & \multicolumn{2}{|c|}{$1,518 / 2,978$} \\
\hline
\end{tabular}

